\title{
Metal leaching from a spent catalyst by Alternaria alternata
}

\section{Lixiviación de metales a partir de un catalizador agotado por Alternaria alternata}

Norma G. Rojas-Avelizapa*, Jessica Otamendi-Valdez, Marlenne Gómez-Ramírez

Departamento de Biotecnología, Centro de Investigación en Ciencia Aplicada y Tecnología Avanzada del Instituto Politécnico Nacional, México, Queretaro.

*Corresponding author.

E-mail address: nrojasa@ipn.mx (N. G. Rojas-Avelizapa).

Received: 23 February 2017 / Received in revised form: 26 May 2017 / Accepted: 20 June 2017 / Published online: 1 July 2017.

https://doi.org/10.29267/mxjb.2017.2.2.221

\begin{abstract}
The study evaluated the leaching ability of the extracellular medium produced by a fungus, which was identified as Alternaria alternata. The study included the selection of a culture medium that favored the organic acid and siderophore production; sucrose and Czapek media were evaluated. Once the culture media was selected, bioleaching study of the catalyst at 1 and $5 \%$ continued, using only the extracellular media incubating at $30^{\circ} \mathrm{C}, 150$ rpm during 7 days. Results indicated that the extracellular media produced by A. alternata in sucrose media decreases $\mathrm{pH}$ from 6 to 4.8; in this media siderophores were also produced. The study of metal bioleaching, using the extracellular media, showed that metals were leached at different extent, and it was observed that catalyst concentration had an important effect on the metal removal and on the order of the removal. It was found that at $1 \%$ catalyst and after $48 \mathrm{~h}$ of treatment, the following metals were removed, in descending order, $\mathrm{V}>\mathrm{Al}>\mathrm{Si}>\mathrm{Mo}>\mathrm{Mg}>\mathrm{Fe}>\mathrm{Ni}>\mathrm{As}>\mathrm{Cr}$. This is the first report on the metal removal from the catalyst by the extracellular media of A. alternata which opens new research alternatives for the treatment of hazardous wastes with high metallic content.
\end{abstract}

Keywords: Bioleaching, Fungi, Leaching agent, Siderophore, Spent catalyst.

\section{RESUMEN}

El estudio evaluó la habilidad de lixiviación del medio extracelular producido por un hongo, el cual fue identificado como Alternaria alternata. El estudio comprendió la selección de un medio de cultivo que favorece la producción de ácidos orgánicos y de sideróforos, los medios de cultivo evaluados fueron medio de sacarosa y Czapek. Una vez 
seleccionado el medio de cultivo, se continuó con el estudio de biolixiviación de metales de un catalizador al 1 y $5 \%$, utilizando el medio extracelular en medio de sacarosa e incubando a $30^{\circ} \mathrm{C}, 150 \mathrm{rpm}$ durante 7 días. Los resultados indicaron que el medio extracelular disminuyó su $\mathrm{pH}$ de 6 a 4.8; en este medio se producen sideróforos. El estudio de lixiviación de metales en presencia del catalizador demostró que el extracto del hongo es capaz de lixiviar metales; la concentración del catalizador tiene un efecto importante sobre la remoción de los metales y sobre la especificidad hacia los metales; a una concentración de catalizador del 1\%, se removieron los siguientes metales, en orden descendente, $\mathrm{V}>\mathrm{Al}$ $>\mathrm{Si}>\mathrm{Mo}>\mathrm{Mg}>\mathrm{Fe}>\mathrm{Ni}>\mathrm{As}>\mathrm{Cr}$ después de $48 \mathrm{~h}$. Este es el primer reporte sobre la remoción de metales a partir de un catalizador por el medio extracelular de A. alternata lo cual abre nuevas alternativas de investigación para el tratamiento de residuos peligrosos con alto contenido metálico.

Palabras clave: Agente lixiviante, Biolixiviación, Catalizador agotado, Hongos, Sideróforos.

\section{INTRODUCTION}

The oil refining process use great amounts of catalysts, however due to their extensive use they become inactivated due to poisoning by foreign materials and impurities; then they are discharged and disposed representing an environment concern since spent catalysts are considered as hazardous wastes due to their high metals content. Catalysts contain a wide variety of metals such as $\mathrm{Al}, \mathrm{Mo}, \mathrm{Ti}, \mathrm{V}, \mathrm{C}, \mathrm{Ni}$ among others; they facilitate different oil transformations. Actually, there are different metallurgical processes for their treatment; the most used are the hydro-pyrometallurgical ones. These methods dissolve the valuable metals efficiently, however significant amounts of pollutants are released to the environment, and that is the reason why they are not considered ecological methods.

The use of biological processes such as bioleaching, which is based on the ability of microorganisms or their byproducts to transform solid compounds into soluble and extractable elements represent a good alternative that can be considered as a clean technology due to their low requirements in cost and energy, if these are compared to the traditional methods.

Diverse microorganisms have been reported for the bioleaching of heavy metals contained in solid wastes including Aspergillus niger, Penicillium simplicissimum, Penicillium purpurogenum, Rhodotorula rubra, Acidithiobacillus thiooxidans and Acidithiobacillus ferrooxidans (Deng et al., 2013). Most studies have been performed with bacteria although fungi appear as promising but studies are scarce. Some species of heterotrophic fungus (e.g., Aspergillus and Penicillium) have shown potential for metal bioleaching of various waste materials, such as fly ash, spent catalysts and electrical wastes. The most important mechanism of metal leaching by heterotrophic fungus is an indirect process, that is, by the microbial production of metabolites such as amino acids, organic acids or siderophores (Yang and Bin, 2013; Deng et al., 2013). The aim of the present study was to determine the role of fungal metabolites, contained in extracellular media, such as organic acids and siderophores in the bioleaching of metals contained in a spent catalyst. 


\section{MATERIALS AND METHODS}

\subsection{Fungus strain}

Isolate MVSS-AH-5 was obtained from a site with high metallic content located in Guanajuato, México; it was identified by molecular techniques in the Biotechnology Genomic Center of the National Polytechnic Institute.

\subsection{Fungus Identification}

A collection of taxonomically related sequences was obtained from the NCBI Taxonomy Homepage and used to perform a multiple alignment analysis with CLUSTAL W (Larkin et al., 2007) and T-Coffee (Magis et al., 2014). Only common 16Sr and ITS genes regions were included in the phylogenetic tree, and similarity analyses using the Jukes-Cantor model were performed with the MEGA 5.2 (Tamura et al., 2011). The phylogenetic tree was constructed using the UPGMA method, and 1000 bootstrap replications were assessed to support internal branches (Hillis and Bull, 1993). Sequences with identity scores to wellcharacterized 16S and ITS sequences greater than 97\% identity ( $<3 \%$ divergence) were resolved at the specie level, between $95 \%$ and $97 \%$ at the genus level (Rosello-Mora and Amann, 2001).

\subsection{Hydrotreating catalyst}

The spent catalyst used in the present study was coded as Ecat-Ni/V-H-oil, which was prepared from three different spent catalysts. The Mexican Petroleum Institute provided catalyst. Metallic content was determined by ICP-EOS following the methodology explained later. The particle size was lower than $500 \mu \mathrm{m}$. The catalyst was stored at room temperature.

\subsection{Effect of culture media on fungal metabolites production}

Isolate MNSS-AH-5 was cultivated on potato dextrose agar plates and was kept in an incubator at $30^{\circ} \mathrm{C}$ until sporulation. The conidia suspension of fungus was prepared at $1 \times 10^{7}$ conidia/mL, which was determined in a Newbauer chamber. To obtain fungal metabolites, two media were evaluated: sucrose (Aung and Ting, 2005) and Czapek media (Deng et al., 2013) as follows: 10\% (3 mL) of conidia solution were inoculated in $50 \mathrm{~mL}$ Erlenmeyer flasks containing $30 \mathrm{~mL}$ of media, then systems were incubated at $30^{\circ} \mathrm{C}, 150$ rpm during 7 days. Every $24 \mathrm{~h}$, organic acid production was indirectly determined by $\mathrm{pH}$ in supernatant according to NMX-AA-008-SCFI-2011 method, using a digital potentiometer (PerpHecT LogR meter 310) and siderophores production was determined by CAS method as follows.

\subsection{Evaluation of siderophore production}

The siderophore production was determined by chrome azurol S (CAS) method (Milagres et al., 1999; Santos et al., 2014). Briefly, the CAS method consist on mixing $0.5 \mathrm{~mL}$ of the cell-free filtrate with $0.5 \mathrm{~mL}$ of CAS assay solution and $1 \mathrm{~mL}$ of distilled water. The 
mixture was allowed to equilibrate during $2 \mathrm{~h}$ in the dark at room temperature; later the absorbance was measured at $630 \mathrm{~nm}$. Adjustment to cero absorbance was done with a mixture containing the same volume of CAS; the volume of cell-free filtrate was replaced by culture medium. Positive reactions were recorded by a change in the color of the CAS reagent from blue to yellow, light orange, orange or purple (Silva-Stenico et al., 2005; Perez-Miranda et al., 2007). Siderophore content in aliquot was calculated by using following formula (Afreen et al., 2014):

$$
\% \text { Siderophore unit }(\% \mathrm{SU})=(\mathrm{Ar}-\mathrm{As} / \mathrm{Ar}) \times 100
$$

\section{Where:}

$\mathrm{Ar}=$ absorbance of reference (non inoculated $\mathrm{SM}+\mathrm{CAS}$ reagent)

As $=$ absorbance of sample (supernatant of production medium + CAS reagent) at $630 \mathrm{~nm}$

For bioleaching studies, the extracellular media obtained at those previously selected conditions ( $\mathrm{pH}$ reduction and maximal siderophore production) was produced and then used. However, to obtain a higher amount of media, in this case, extracellular media was produced in $1 \mathrm{~L}$ Erlenmeyer flasks containing $250 \mathrm{~mL}$ of sucrose medium as mentioned above; then at the appropriate time, fungus biomass was harvested and then extracellular media was vacuum filtered through sterile fine pore filter paper; the media containing the leaching agent was passed through $0.22 \mu \mathrm{m}$ membrane (Whatman) to obtain the cell-free leaching media which was used for further studies.

\subsection{Bioleaching of metals from spent catalyst}

To evaluate the leaching of metals from spent catalyst by the extracellular media from fungus, two experimental sets were prepared in $50 \mathrm{~mL}$ Erlenmeyer flasks containing $15 \mathrm{~mL}$ of fungus leaching media; a) catalyst was used al $1 \%$ pulp density and b) catalyst was added at $5 \%(\mathrm{w} / \mathrm{v})$ pulp density and then incubated at $30^{\circ} \mathrm{C}, 150 \mathrm{rpm}$ during $48 \mathrm{~h}$. All experiments were done in duplicate. Controls containing sucrose media plus spent catalyst at $1 \%$ and $5 \%(\mathrm{w} / \mathrm{v})$ pulp density were also included in order to evaluate the abiotic leaching. At the end of experimentation, total content of flasks was separated by filtration then the catalyst was dried at room temperature; filtrate was collected in $50 \mathrm{~mL}$ glass vials and stored at $4{ }^{\circ} \mathrm{C}$ until be analyzed by ICP-EOS (Gómez-Ramírez et al., 2015). Metal removal from catalysts due to extracellular media was reported as the difference between the metal concentrations in controls and those concentrations in treatments.

\subsection{Digestion and analysis of metals}

Metal concentrations (bioleached) in liquid media and those remaining in catalysts were determined at the beginning and at the end of treatment. Samples of $1 \mathrm{~mL}$ of liquid samples or $100 \mathrm{mg}$ of spent catalyst were subjected to metal analyses using an ICP-OES, Varian Model 710-ES after acid digestion. Catalyst treated was placed in cylindrical vial of silicon carbide, $6 \mathrm{~mL}$ of $\mathrm{HNO} 3$ and $2 \mathrm{~mL}$ of $\mathrm{HCl}$ were added; samples were digested in a Microwave Reactions System: Multiwave PRO (Anton Paar), using a rotor HF100. Digestion conditions were: power $800 \mathrm{~W}$ for eight vessels, 40 Bar, temperature $210-240^{\circ} \mathrm{C}$, with pRate of $0.3 \mathrm{bar}$ seg-1, ramp $15 \mathrm{~min}$, hold $20 \mathrm{~min}$ and cooling $15 \mathrm{~min}$. Afterwards, $20 \mathrm{~mL}$ of deionized water 
was added to cylindrical vial and the supernatant was collected in a $100 \mathrm{~mL}$ flask and set with deionized water. Metal analysis was performed using different wavelengths (nm) according with the metal. Metal concentrations in spent catalyst were calculated based on calibration curve of 0.1 - 10 ppm using a commercial standard (High-Purity) Cat. \# ICP-200.7-6. The data were statistically analyzed using the Minitab 17 software with Tukey's HSD pairwise comparisons.

\section{RESULTS}

As can be observed in Table 1, ICP analyses showed that catalyst was composed mainly by aluminum; other elements were also presented however, although their concentration in catalyst is important when catalyst was used at 1 and 5\% (w/v) the concentration was low.

Table 1. Elemental composition of the spent catalyst analyzed by ICP-EOS

\begin{tabular}{l|l|l|l}
\hline Metal & $\mathbf{m g} / \mathbf{k g}$ & Metal & $\mathbf{m g} / \mathbf{k g}$ \\
\hline $\mathrm{Al}$ & 195482.7 & $\mathrm{Mg}$ & 1615.5 \\
$\mathrm{Si}$ & 28324.5 & $\mathrm{As}$ & 1349.8 \\
$\mathrm{~V}$ & 17185.8 & $\mathrm{Zn}$ & 190.9 \\
$\mathrm{Fe}$ & 11742.8 & $\mathrm{Cr}$ & 153.6 \\
$\mathrm{Mo}$ & 6224.8 & $\mathrm{Sn}$ & 146.4 \\
$\mathrm{Ni}$ & 2765.8 & $\mathrm{~Pb}$ & 62.2 \\
$\mathrm{P}$ & 2111.4 & $\mathrm{Cd}$ & 47.6 \\
$\mathrm{Sr}$ & 25.3 & $\mathrm{Cu}$ & 23 \\
\hline
\end{tabular}

\subsection{Fungus identification}

As it was mentioned previously, isolate coded MVSS-AH-5 was identified by molecular techniques. Fig. 1 shows the cladogram were isolate MVSS-AH-5 was identified as Alternaria alternata.

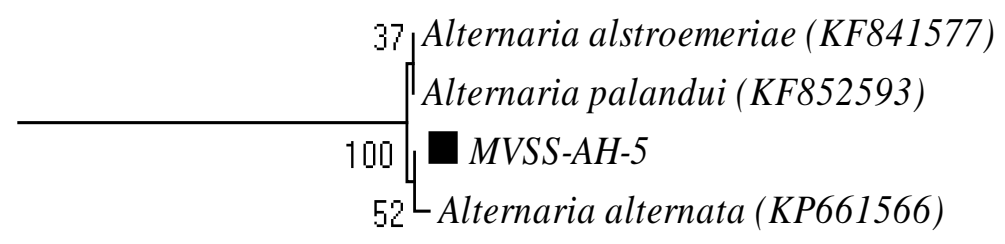

Mucor guilliermondii (JN206082)

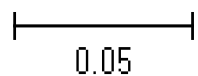

Fig. 1. The cladogram was constructed by using MEGA 6 software by Tamura et al., (2011). Evolutionary relationships were estimated by UPGMA method (Sneath and Sokal, 1973) with 1000 bootstrap value to obtain the consensus tree (Felsenstein, 1985). Evolutionary distances were calculated using the Jukes-Cantor method (Jukes, 1969). Mucor guillermondi was used as the outgroup. Bar 0.05 substitutions per nucleotide position. 


\subsection{Effect of culture media on fungal metabolites production}

In Fig. 2, it is observed that the $\mathrm{pH}$ reduction was observed only in sucrose media from 6 to 4.8 at $96 \mathrm{~h}$ whereas in Czapek medium no important changes in $\mathrm{pH}$ were detected. In the case of siderophores production, these were evidenced (Fig. 3) because changes in color from blue to orange-yellow were observed within 72-120 h with a maximal production at $96 \mathrm{~h}$. No siderophore production was observed in Czapeck media. Based on these results, further studies were done using sucrose media to produce the extracellular media at $96 \mathrm{~h}$.

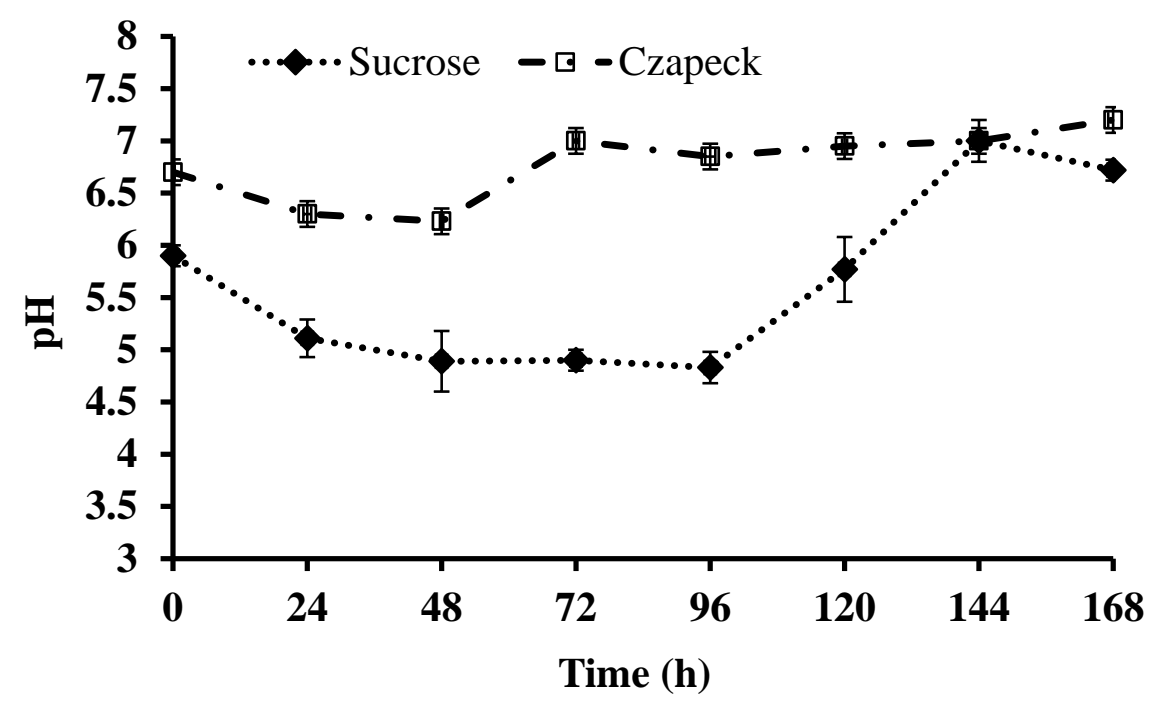

Fig. 2. Monitoring of $\mathrm{pH}$ during the fungus growth in two different media at $30^{\circ} \mathrm{C}, 150$ rpm.

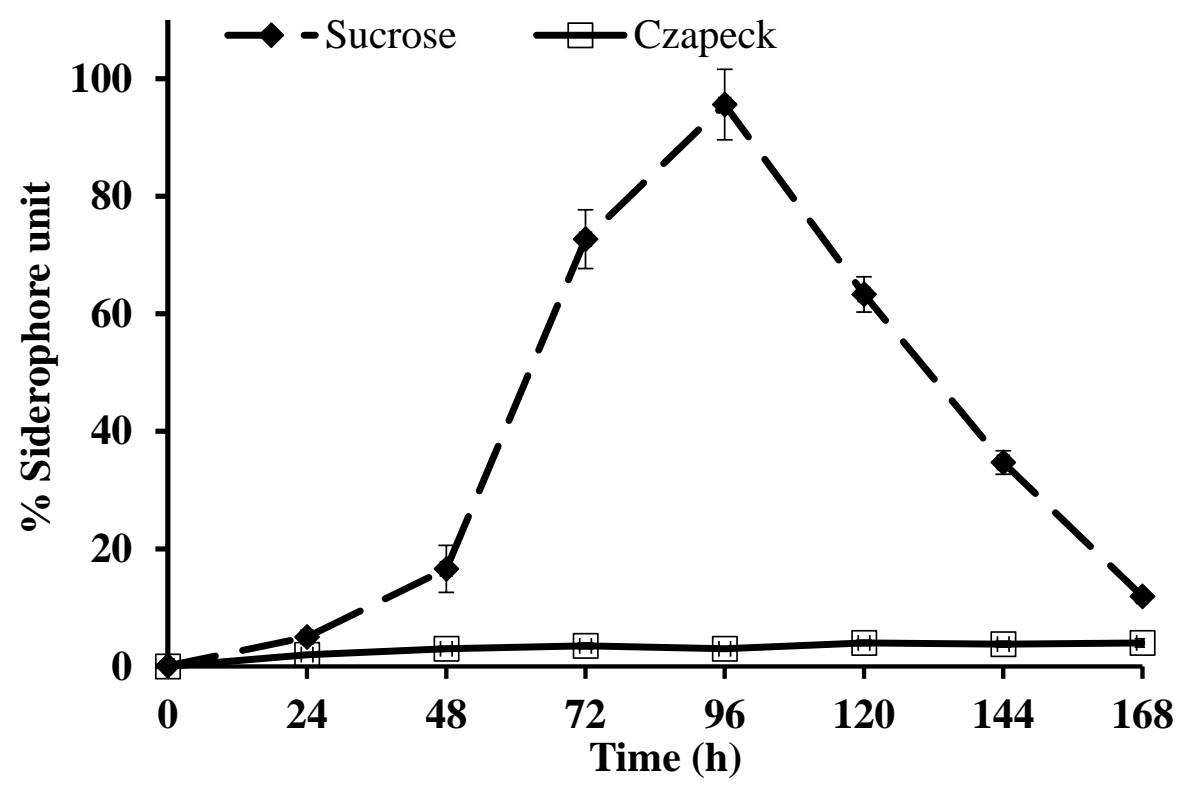

Fig. 3. Monitoring of siderophore production during the fungus growth in two different media at $30^{\circ} \mathrm{C}, 150 \mathrm{rpm}$. 


\subsection{Metal removal from spent catalyst}

According with results, extracellular media produced by A. alternata in sucrose media was able to remove $\mathrm{V}(8285.3 \mathrm{mg} / \mathrm{kg})>\mathrm{Al}(6662.0 \mathrm{mg} / \mathrm{kg})>\mathrm{Si}(4973.8 \mathrm{mg} / \mathrm{kg})>\mathrm{Mo}(3990.2$ $\mathrm{mg} / \mathrm{kg})>\mathrm{Mg}(177.7 \mathrm{mg} / \mathrm{kg})>\mathrm{Fe}(118.2 \mathrm{mg} / \mathrm{kg})>\mathrm{As}(29.9 \mathrm{mg} / \mathrm{kg})$ from the spent catalyst at $1 \%(\mathrm{w} / \mathrm{v})$. Fig. 4 shows the leaching metals detected in liquid media, as can be observed the extracellular media of A. alternata removed more metals than control, except for $\mathrm{Cr}, \mathrm{Ni}$ and $\mathrm{Zn}$, when catalysts was used at $1 \%$. Then, difference in concentrations between treatment and control corresponded to metal removed from catalyst.

When spent catalyst was used at $5 \%$, the metal removal was Al $(9872.7 \mathrm{mg} / \mathrm{kg})>\mathrm{Si}$ $(6839.0 \mathrm{mg} / \mathrm{kg})>$ Mo $(2115.8 \mathrm{mg} / \mathrm{kg})>\mathrm{V}(1903.0 \mathrm{mg} / \mathrm{kg})>\mathrm{Mg}(279.6 \mathrm{mg} / \mathrm{kg})$, although not significant difference was found) after $48 \mathrm{~h}$ of treatment. Fig. 5 shows the leaching metals detected in liquid media, as can be observed the extracellular media of A. alternata removed more metals than control, except for $\mathrm{As}, \mathrm{Cr}, \mathrm{Fe}, \mathrm{Ni}$ and $\mathrm{Zn}$, when catalysts was used at 5\%, a similar behavior than $1 \%$ although the order in metal removal was different. Then, difference in concentrations between treatment and control corresponded to metal removed from catalyst.

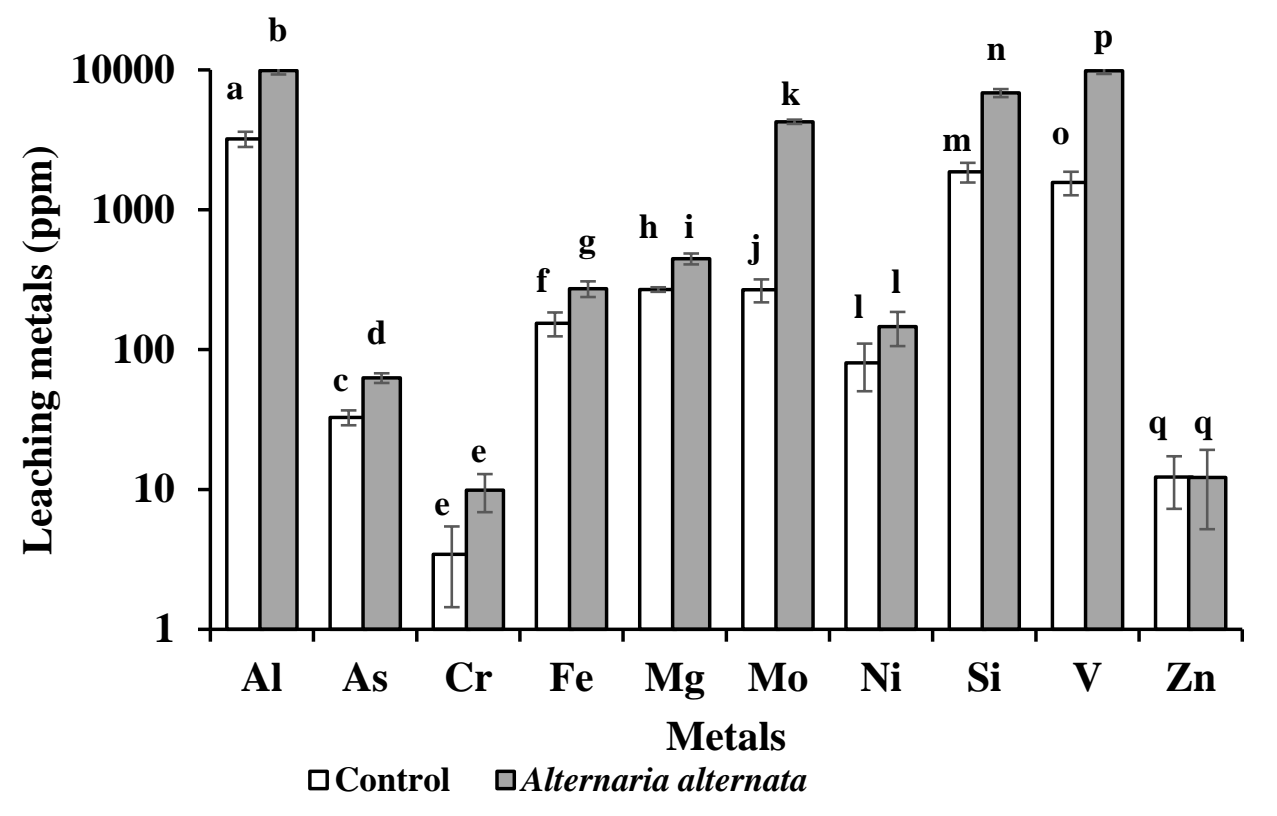

Fig. 4. Bioleaching of metals from spent catalyst at $1 \%$ (w/v) pulp density after 48 of treatment at $30{ }^{\circ} \mathrm{C}, 150 \mathrm{rpm}$ by the extracellular media produced by Alternaria alternata. Statistically significant differences (one-way ANOVA with Tukey's HSD $(\mathrm{P}<0.05)$ are indicated by different letters. 


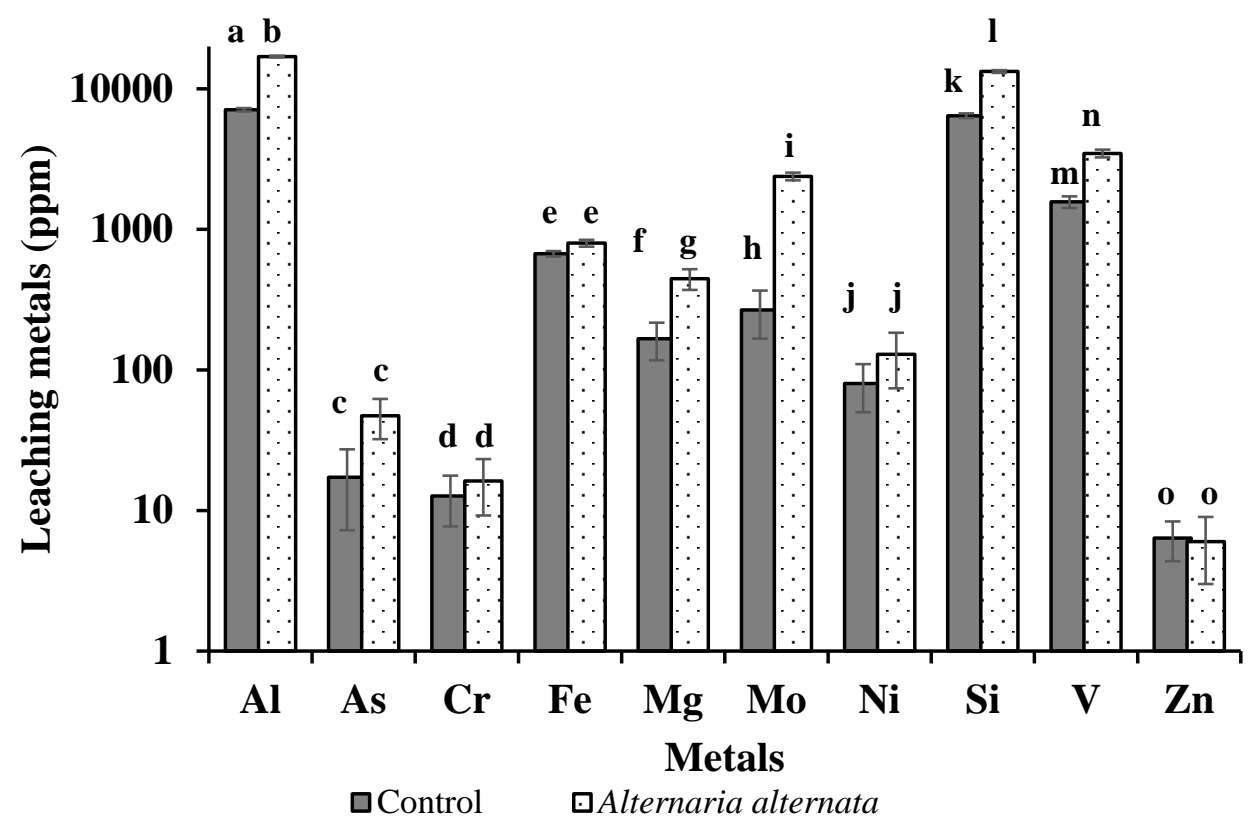

Fig. 5. Bioleaching of metals in spent catalyst at $5 \%$ (w/v) pulp density after 48 of treatment at $30{ }^{\circ} \mathrm{C}, 150 \mathrm{rpm}$ by leaching agent produced by Alternaria alternata. Statistically significant differences (one-way ANOVA with Tukey's HSD $(\mathrm{P}<0.05)$ are indicated by different letters.

To the best knowledge of the authors, this is the first report where extracellular media obtained from A. alternate is used to remove metals from spent catalyst. The highest leaching of different metals was achieved using catalyst at $1 \%$ pulp density.

\section{DISCUSSION}

The genus Alternaria is a cosmopolitan widely distributing in soil and organic matter. At least 268 metabolites from Alternaria fungi have been reported. They include nitrogencontaining metabolites, steroids, terpenoids, pyranones, quinones, and phenolics. Alternaria metabolites exhibit a variety of biological activities such as phytotoxic, cytotoxic, and antimicrobial properties. Some reports mentioned the role of this genus to remove metals however; it has not been reported for the treatment of spent catalysts and less about the use of its extracellular media for metal bioleaching (Lou et al., 2013).

Bioleaching processes of minerals, as can be considered the spent catalyst, require the use of organic acid-producing heterothrophic microorganisms or other chelating agents, most studied genera are Aspergillus and Penicillium. The organic acids could aid the solubilisation of hard and complex mineral materials as spent catalyst since it has been reported that organic acids are low-molecular weight carbon compounds capable to form complexes with various minerals. The actions of these organic acids can occur in two different ways: a) direct mineral attack by the metal-complexing organic acid anions as well as protons and b) there is a structural similarity between protons from organic acids and from monovalent elements so they can be substituted. Therefore, an important 
screening process for bioleaching microbes involves the direct or indirect evaluation of the ability of the microorganisms to produce organic acids. Previous studies performed by our research group showed that Penicillium sp and Acremonium $s p$ are able to remove metals from spent catalyst (Gómez-Ramírez et al., 2015) however some drawbacks have been considered for field application, so in this study the first step was to evaluate the culture media where $A$. alternata produce organic acids. In addition, siderophore production was evaluated at the same conditions.

Siderophores have received much attention in recent years because of their potential roles and applications in various areas of environmental research. Their significance in these applications is because siderophores have the ability to bind a variety of metals in addition to iron, and they have a wide range of chemical structures and specific properties. The role of siderophores is primarily to scavenge Fe, but they also form complexes with other essential elements (i.e. Mo, Mn, Co and $\mathrm{Ni}$ ) in the environment and make them available for microbial cells (Bellenger et al., 2008). Results of the present study evidenced the production of organic acids by measuring $\mathrm{pH}$ decreasing (6.8 a 4.83) and siderophores (95\%) by CAS method, respectively, in sucrose media by A. alternata. In Czapeck media, no organic acids ( $\mathrm{pH}$ decreasing) or siderophores were produced. Therefore, more studies were done using the sucrose media. Although other chelating agents or compounds could be produced in liquid media of $A$. alternata only these mechanisms are exposed.

Regarding organic acids, it has been reported that organic acids leached more heavy metals than inorganic acids (Yixin Ya, 2014). The pathway of metal leaching is directly related to the coordinative ability of organic acids and metal ions. The more stable of the ligand formed, the more difficult to be adsorbed by the soil and sediment, and thus the metal leaching is much easier (Gao et al., 2003). A number of studies of heavy metal pollution of soil have verified that the reactions between organic acid and heavy metal are related to the amount and place of the carboxyl and hydroxyl groups (Gao et al., 2002). Generally, the structure with more carboxyl groups is beneficial to the heavy metal leaching.

Based on results and previous information, the study showed the ability of the extracellular media of $A$. alternata to leach or mobilize different metals from spent catalyst at 1 and $5 \%$ probably by means of sideorophore or organic acids although more studies are needed to demonstrate it. The extracellular media of A. alternata mobilized metals at different extent when catalyst was used at 1 or $5 \%$. The reason why this could occurs it is not completely understood due to the complex nature of the catalyst and due to the affinity of each metal to siderophores or organic acids.

Summarizing, this study report for the first time the use of the extracellular media of $A$. alternata containing organic acids and siderophores for the metal leaching from a spent catalyst. This media is able to leach metals although the mechanisms are unknown however, it is suggested that siderophores and organic acids production are involved. Nowadays, there are interest in the search of clean technologies to decrease the environmental impact of the chemicals industry, then the use of biological leaching using fungus or their metabolites could be a good alternative to treat non- sulfur materials with high metallic content. The leaching agent produced by Alternaria alternata could be suggested for the treatment of spent catalyst that came from oil industry. 


\section{ACKNOWLEDGEMENTS}

This research received financial support by SEP-CONACYT 131203 and SIP20161367 of National Polytechnic Institute.

\section{CONFLICT OF INTEREST}

All the researchers listed as authors of the current study declare that there is no conflict of interests regarding the publication of this manuscript.

\section{REFERENCES}

Afreen J.M. \& Meera C.D. 2014. Siderophore Produced by Bacillus spp GN-01Isolated from Rhizosphere of Ground Nut Field. International Journal of Pharmaceutical and Phytopharmacological Research. 3(4):311-313.

Aung K.M.M. \& Ting Y.P. 2005. Bioleaching of spent fluid catalytic cracking catalyst using Aspergillus niger. Journal of Biotechnology. 116:159-170.

Bellenger J.P., Wichard T., Kustka A.B. \& Kraepiel A.M.L. 2008. Uptake of molybdenum and vanadium by a nitrogen-fixing soil bacterium using siderophores. Natural Geosciences. $1: 243-246$.

Deng X., Chai L., Yang Z., Tang C., Wang Y. \& Shi Y. 2013. Bioleaching mechanism of heavy metals in the mixture of contaminated soil and slag by using indigenous Penicillium chrysogenum strain F1. Journal of Hazardous Materials. 248-249:107- 114

Felsenstein, J. 1985. Confidence limits on phylogenies: An approach using the bootstrap. Evolution. 39: 783-791.

Gao, Y. Z., He, J. Z., Ling, W. T., Hu, H. Q. \& Liu, F. 2003. Effects of organic acids on copper and cadmium desorption from contaminated soils. Environment International, 29: 613-618.

Gómez-Ramírez M., Plata-González A., Fierros-Romero G. \& Rojas-Avelizapa N.G. 2015. Novel Filamentous Fungi for Metal Removal from Spent Catalyst. Advanced Materials Research. 1130: 673-676.

Hillis D.M. \& Bull J.J. 1993. An empirical test of bootstrapping as a method for assessing confidence in phylogenetic analysis. Systematic Biology. 42:182-192.

Jukes T.H. \& Cantor C.R. 1969. Evolution of protein molecules. In Mammalian Protein Metabolism. Munro H.N., Eds., Academic Press, New York. pp 21-132.

Larkin M.A,, Blackshields G,, Brown N,P,, Chenna R,, McGettigan P,A,, McWilliam H,, Valentin F,, Wallace I,M, Wilm A, Lopez R,, Thompson J,D, Gibson T,J, \& Higgins D,G. 2007. Clustal W and Clustal X version 2.0. Bioinformatics 23: 2947-2948. 
Lou J., Fu L., Peng Y. \& Zhou L. 2013. Metabolites from Alternaria Fungi and Their Bioactivities. Molecules. 18(5): 5891-5935.

Magis C., Taly J.F., Bussotti G., Chang J.M., Di T. P. et al. 2014. T-coffee: tree-based consistency objective function for alignment evaluation. Methods Molecular Biology. 1079:646-647.

Mexican Norm (NMX-AA-008-SCFI-2011). Water analysis-Determination of pH-Tests method, (Secretaria de comercio y Fomento Industrial) 2011.

Milagres A.M.F., Machuca A. \& Napoleao D. 1999. Detection of siderophore production from several fungi and bacteria by a modification of chrome azurol S (CAS) agar plate assay. Journal of Microbiological Methods. 37:1-6.

Pérez-Miranda S., Cabiro 1.N., George-Téllez R., Zamudio-Rivera L.S. \& Fernández F.J. 2007. O-CAS, a fast and universal method for siderophore detection. Journal of Microbiological Methods. 70:127-13.

Rossello-Mora R. \& Amann R. 2001. The species concept for prokaryotes. FEMS Microbiology Reviews. 25:39-67.

Santos S., Neto F.F.I., Machado D.M., Soares M.V.M.E. \& Soares E.V. 2013. Siderophore Production by Bacillus megaterium: Effect of Growth Phase and Cultural Conditions. Applied Biochemistry and Biotechnology.172:549-560

Silva-Stenico M.E., Pacheco H.F.T., Rodrigues M.J.L., Carrilho E. \& Tsai S.M. 2005. Growth and siderophore production of Xylella fastidiosa under iron-limited conditions. Microbiological Research .160: 429-436

Sneath P.H.A. \& Sokal R.R. 1973. Numerical Taxonomy: The Principles and Practice of Numerical Classification; W.H. Freeman, San Francisco.

Tamura K., Peterson D., Peterson N., Stecher G., Nei M. \& Kumar S. 2011. MEGA5: molecular evolutionary genetics analysis using maximum likelihood, evolutionary distance, and maximum parsimony methods. Molecular Biology Evololution. 28:2731-2739.

Yang Q. \& Bin L. 2013. Bioleaching of rare earth and radioactive elements from red mud using Penicillium tricolor RM-10. Bioresource Technology. 136:16-23.

Yixin Yan, Jianlei Gao, Jianping Wu, \& Bei Li. 2014. Effects of Inorganic and Organic Acids on Heavy Metals Leaching in Contaminated Sediment In An Interdisciplinary Response to Mine Water Challenges - Sui, Sun \& Wang (eds). China University of Mining and Technology Press, Xuzhou, ISBN 978-7-5646-2437-8. 